\title{
The Duty to Charge in Police Use of Excessive Force Cases
}

Rebecca Roiphe

New York Law School, rebecca.roiphe@nyls.edu

Follow this and additional works at: https://digitalcommons.nyls.edu/fac_articles_chapters

Part of the Civil Rights and Discrimination Commons, Human Rights Law Commons, and the Law Enforcement and Corrections Commons

\section{Recommended Citation}

Cleveland State Law Review, Vol. 65, Issue 4 (2017), pp. 503-518

This Article is brought to you for free and open access by the Faculty Scholarship at DigitalCommons@NYLS. It has been accepted for inclusion in Articles \& Chapters by an authorized administrator of DigitalCommons@NYLS. 


\title{
THE DUTY TO CHARGE IN POLICE USE OF EXCESSIVE FORCE CASES
}

\author{
REBECCA ROIPHE*
}

\begin{abstract}
Responding to the problems of mass incarceration, racial disparities in justice, and wrongful convictions, scholars have focused on prosecutorial overcharging. They have, however, neglected to address undercharging - the failure to charge in entire classes of cases. Undercharging can similarly undermine the efficacy and legitimacy of the criminal justice system. While few have focused on this question in the domestic criminal law context, international law scholars have long recognized the social and structural cost for nascent democratic states when they fail to charge those responsible for the prior regime's human rights abuses. This sort of impunity threatens the rule of law and misses the opportunity to reinforce important democratic values. This Article draws on international law scholarship to argue that there is a duty to investigate and a limited duty to charge crimes that implicate core democratic principles of equality and fairness. Police use of excessive force against unarmed African-American suspects is just this sort of crime.
\end{abstract}

CONTENTS

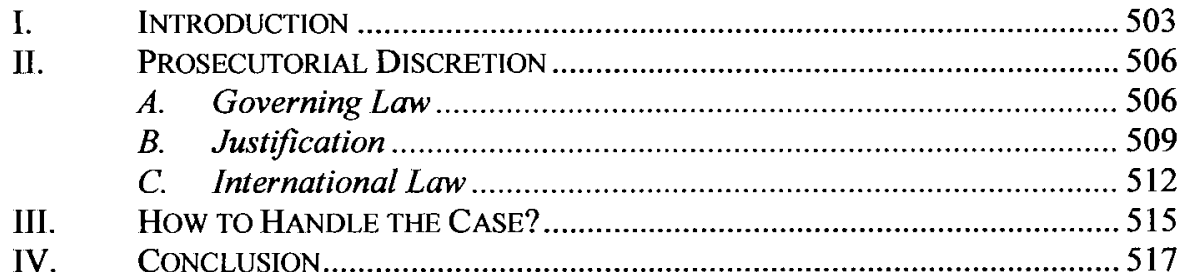

\section{INTRODUCTION}

The United States is in the midst of what seems like an epidemic of police shootings of unarmed black men. Cell phone videos made by bystanders or friends of the victims animate the injustice. Black Lives Matter activists have mobilized the resulting anger into a powerful social movement. Amidst all of this unrest, very few of the involved police officers have been prosecuted. ${ }^{1}$ Even fewer have been

* Professor of Law, New York Law School. J.D. Harvard Law School, Ph.D. University of Chicago. I would like to thank Professor Ruti Teitel, whose scholarship inspired this paper. Many thanks as well to the participants in the Symposium at Cleveland-Marshall College of Law for their thoughtful comments.

1 One notable exception is a case in Charleston, which led to federal charges against the officer for shooting an unarmed black man in the back. Chris Dixon \& Tamar Lewin, South Carolina Officer Faces Federal Charges in Fatal Shooting, N.Y. TIMES (May 11, 2016), http:/www.nytimes.com/2016/05/12/us/south-carolina-officer-faces-federal-charges-in-fatalshooting.html. 
convicted and punished. ${ }^{2}$ Highlighting the difficulty inherent in these cases, the Department of Justice ("DOJ") has reorganized its inquiry into the killing of Eric Garner in Staten Island. ${ }^{3}$ In 2014, police officers approached Garner and accused him of selling loose cigarettes. ${ }^{4}$ The officers then attempted to arrest Garner for his alleged conduct. ${ }^{5}$ When Garner refused to submit, Officer Daniel Pantaleo used a chokehold to subdue him. Garner died after repeating "I can't breathe" to the officers surrounding him. ${ }^{6}$ The entire incident was caught on video, spurring protests around the country. After a Staten Island grand jury refused to indict Pantaleo, the DOJ launched an investigation into a potential civil rights violation. ${ }^{7}$ The investigatory team has subsequently split between the Federal Bureau of Investigation (FBI) agents and Brooklyn prosecutors-who do not believe charges are appropriate-and those within the Civil Rights Division-who disagree. ${ }^{8}$

The controversy over the Eric Garner case illustrates both how difficult it is to make decisions in these sensitive cases and the relative lack of guidance on when it is appropriate, or even necessary, to bring charges. Criminal justice scholars have examined and criticized prosecutors' tendency to overcharge, bringing too many charges against too many suspects. ${ }^{9}$ However, few have looked at the question of when, if ever, a prosecutor must charge a case. There is no legal obligation for prosecutors to seek indictments, even when the evidence supports a conviction. Nevertheless, the question remains whether it would ever constitute an abuse of discretion to fail to bring charges. This Article argues that prosecutors must investigate and seek to indict in police shooting cases when there is sufficient evidence to support charges. It is an abuse of discretion to fail to do so because the

2 Three of the officers accused of killing Freddie Gray in Baltimore were acquitted, and the charges against the remaining officers were dismissed. Carolyn Sung \& Catherine E. Shoichet, Freddie Gray Case: Charges Dropped Against Remaining Officers, CNN (July 27, 2016), http://www.cnn.com/2016/07/27/us/freddie-gray-verdict-baltimore-officers/.

3 Matt Apuzzo et al., Justice Dept. Shakes up Inquiry into Eric Garner Chokehold Case, N.Y. TIMES (Oct. 24, 2016), http://www.nytimes.com/2016/10/25/nyregion/justice-deptreplaces-investigators-on-eric-garner-case.html.

4 Id.

5 Al Baker et al., Beyond the Chokehold: The Path to Eric Garner's Death, N.Y. TIMES (June 13, 2015), https://www.nytimes.com $/ 2015 / 06 / 14 /$ nyregion/eric-garner-policechokehold-staten-island.html.

6 Apuzzo et al., supra note 3.

7 Id.

8 Id

9 See, e.g., Richard L. LiPPKE, The ETHICS of Plea Bargaining (2012); Kyle Graham, Overcharging, 11 OHIO ST. J. CRIM. L. 701, 704-05 (2014); Bennett L. Gershman, Prosecutorial Decisionmaking and Discretion in the Charging Function, 62 HASTINGS L. J. 1259, $1279-81$ (2011); Josh Bowers, Legal Guilt, Normative Innocence, and the Equitable Decision Not to Prosecute, 110 ColuM. L. REv. 1655, 1711 (2010); Richard A. Bierschbach \& Alex Stein, Overenforcement, 93 GEO. L. J. 1743, 1756-61 (2005); Tracey L Meares, Rewards for Good Behavior: Influencing Prosecutors' Discretion and Conduct with Financial Incentives, 64 FORDHAM L. REV. 851, 853-54 (1995); Robert E. Scott \& William J. Stuntz, Plea Bargaining as Contract, 101 YaLE L. J. 1909, 1960-64 (1992); Albert Altschuler, The Prosecutor's Role in Plea Bargaining, 36 U. CHI. L. REv. 50, 85-105 (1968). 
crime, which targets a minority group that the criminal justice system has historically neglected and abused, implicates basic democratic principles of equality and fairness.

While domestic criminal law scholars have not explored the question of undercharging, international law scholars have. As states around the world transition to democratic governments, many have debated the question of whether the new government has an obligation to prosecute the perpetrators of human rights abuses under the previous regime. Drawing on international literature, this Article argues that failing to charge a crime implicating fundamental democratic values, such as police shootings of unarmed African-American men, is an abuse of prosecutorial discretion. The inequality in treatment and racial disparity threaten the legitimacy of the system itself. This effect is compounded by the historical treatment of AfricanAmericans in criminal courts. ${ }^{10}$ International law scholars who study transitional justice have analyzed how the failure to charge can affect new democracies. Along with criminal prosecutions, they have sought alternatives to charging particular offenses, such as truth commissions, to reinforce those values without facing the practical problems of charging every individual who has committed the crime. Drawing on this robust literature, this Article argues that prosecutors have a duty to charge the most culpable offenders in police shooting cases and suggests some alternative mechanisms to supplement the criminal process when prosecution is inappropriate or practical.

To make this argument, this Article first discusses the law governing prosecutorial discretion in charging decisions. Despite efforts to legislate in this area, prosecutors retain broad discretion. With the exception of a few instances in select jurisdictions, there is no legal duty to charge. Next, this Article reviews classic theoretical justifications for prosecution. The Article then looks to international law scholarship for principles to guide domestic prosecutorial decision-making. It concludes by bringing this all to bear on the question of how to handle the growing number of police shootings of unarmed black men.

This Article concludes that is an abuse of discretion not to charge the most culpable police officers, even when the evidence is imperfect or juries are unlikely to convict. It is an abuse of discretion not because there is some absolute right to accountability, but because the vast under-enforcement, especially in light of the historic treatment of African-Americans, undermines the value of equality fundamental to our democratic system. It weakens the legitimacy of the criminal justice system and, with it, democracy itself. Because individual prosecutions will not fully address this deficit, we should also turn to alternate mechanisms to reinforce the fundamental democratic values of fairness, equality, and transparency in the system."

10 See generally Michelle AleXAnder, the New Jim Crow (2010); PAUl Finkelman, RACE AND CRIMINAL JUSTICE (1992).

11 The model rule governing prosecutorial conduct is Model Rule of Professional Conduct 3.8. It imposes limits on when a prosecutor can charge and pursue a prosecution but imposes no affirmative obligation. MODEL RULES OF PROF'L CONDUCT r. 3.8(a) (AM. BAR ASS'N 2017). 


\section{PROSECUTORIAL DISCRETION}

\section{A. Governing Law}

There is no legal or ethical duty to prosecute. In fact, the Rules of Professional Conduct focus more on imposing limits on prosecutors' charging decisions. Prosecutors cannot pursue charges that they know are not supported by probable cause. ${ }^{12}$ The explanatory notes to the American Bar Association's Model Rules of Professional Conduct similarly emphasize the prosecutor's duty to refrain from aggressively seeking convictions by protecting the defendant's procedural rights and ensuring that there is sufficient evidence to convict. ${ }^{13}$ In other words, the rules of professional ethics, like scholars and commentators, attempt to guard against overcharging. To that end, the rules articulate professional obligations that restrain prosecutors from pursuing convictions with too much zeal.

The American Bar Association's criminal justice section also publishes unenforceable guidelines or standards for prosecutors. Like the rules, the standards instruct prosecutors that their job is not just to pursue convictions and that sometimes restraint is in order. ${ }^{14}$ The standards do urge prosecutors to investigate crimes if other agencies fail to do so, ${ }^{15}$ and they state that prosecutors should not be deterred from prosecuting serious crimes by the fact that juries tend to acquit persons accused of similar acts. ${ }^{16}$ By stating these obligations, the bar reminds prosecutors that part of their job is to pursue convictions against the guilty despite political obstacles and any difficulty in proving their cases. Notwithstanding these few reminders, professional standards emphasize obligations to avoid overcharging and give little guidance about when, if ever, prosecutors ought to pursue charges. ${ }^{17}$ They state, for example, that prosecutors have broad discretion in determining if charges are appropriate ${ }^{18}$ and need not prosecute a case even when the evidence supports it. ${ }^{19}$ The standards, like the rules, warn prosecutors against mindlessly seeking convictions. ${ }^{20}$ The professional guidelines do not establish or even hint at a duty to charge or a right of accountability.

12 Id.

13 Id. at cmt. 1.

14 Crim. Just. Sec. Standards For Prosecution Function, Standard 3-1.2(c) (Am. Bar ASS'N 2017).

15 Id. at Standard 3-3.1(a).

16 Id. at Standard 3-3.9(e).

17 See generally id.

18 Id. at Standard 3-3.4(a).

19 Id. at Standard 3-3.9(a), (b).

20 Id. at Standard 3-3.6(c) (urging prosecutors to recommend that the grand jury not indict if he or she believes the evidence does not warrant it); see also id. at Standards 3-3.8 (urging prosecutors to consider noncriminal disposition in appropriate cases and noting that prosecutors should be familiar with social agencies that can divert cases from the criminal process), 3-3.9(d) (stating that in making the decision to charge, prosecutors should give no weight to personal or political advantage), 3-3.9(f) (stating that prosecutor should not seek charges greater than can be supported by the evidence and fairly reflect the crime). 
Courts similarly shy away from invitations to regulate prosecutors' charging decisions. In doing so, case law acknowledges that the prosecutor has a quasijudicial role with broad discretion to determine when charges are appropriate. ${ }^{21}$ In State $v$. Winne, for instance, a New Jersey court dismissed an indictment against a prosecutor for failing to charge individuals with illegal gambling. ${ }^{22}$ Amidst concerns about gambling and official corruption, a special prosecutor sought to indict the Bergen County District Attorney for failing to prosecute those involved in the criminal syndicate. ${ }^{23}$ The court insisted that such a prosecution for nonfeasance of a public duty should only proceed if the state could prove evil motive. ${ }^{24}$ Otherwise, the court reasoned, prosecutors would be fearful in declining to bring charges, which constitutes an essential part of their official discretion. ${ }^{25}$ The court reasoned that a prosecutor could choose to commence or drop charges for a number of reasons. ${ }^{26}$ It is the prosecutor's job to weigh countless factors in determining what justice requires. ${ }^{27}$ Indicting the prosecutor for failing to pursue gambling cases would interfere with the administration of justice by injecting a fear of retribution into the prosecutors' determination, which ought to be motivated solely by the interests of justice.

In federal court, Federal Rule of Criminal Procedure 48(a) provides that the government can dismiss an indictment, information, or complaint "with leave of the court."28 The Supreme Court declined to decide whether courts could deny prosecutors' uncontested motions to dismiss charges. ${ }^{29}$ In doing so, it noted that a court's review is primarily designed to protect defendants from harassment, but there may also be a limited right to review prosecutors' decisions if they are clearly contrary to the public interest. ${ }^{30}$ Most jurisdictions that have considered this

21 State v. Winne, 91 A.2d 65, 65 (N.J. Super. Ct. Law Div. 1952).

22 Id.

23 Id.

24 Id.

25 Id. at 79 .

26 Id. at 77 .

27 Id.

28 Fed. R. CRIM. P. 48(a).

29 United States v. Gonzales, 58 F.3d 459, 461 (9th Cir. 1995).

30 Rinaldi v. United States, 434 U.S. 22, 34 n.15 (1977). Most federal courts similarly restrict the courts' ability to deny the government's motion to dismiss an indictment to cases in which it is clearly in the public interest to do so. See United States v. Smith, 55 F.3d 157, 159 (5th Cir. 1995) (holding that the court must grant motions that are not motivated by bad faith); United States v. Ammidown, 497 F.2d 615, 620 (D.C. Cir. 1973) (stating that the primary purpose of Rule $48(a)$ is to protect a defendant from "harassment, through a prosecutor's charging, dismissing without having placed a defendant in jeopardy, and commencing another prosecution at a different time or place deemed more favorable to the prosecution," but the court can also ask for an explanation of why the dismissal is in the public interest). The Seventh Circuit read the rule more narrowly to prohibit courts from denying an uncontested motion, even if the court found that the prosecution was acting in bad faith. In re United States, 345 F.3d 450, 453 (7th Cir. 2003); see also United States v. JacoboZavala, 241 F.3d 1009, 1013 (8th Cir. 2001) (stating courts can only deny a motion to dismiss 
particular issue refuse to allow courts to deny uncontested motions for dismissal except in extreme cases. ${ }^{31}$ Like the court in Winne, federal courts recognize that prosecutors are better situated to evaluate the propriety of a criminal charge. ${ }^{32}$ Separation of powers concerns mandate a narrow review of charging decisions.

In general, only the elected or appointed prosecutor can decide whether to bring charges. ${ }^{33}$ Some states, however, have statutes allowing private citizens to petition courts or other officials to prosecute alleged criminal conduct. Concerned citizens used such a law in Ohio to request a grand jury investigation into Officer Timothy Loehmann for killing Tamir Rice, a twelve-year old African-American boy, who was shot while reaching for a toy gun. ${ }^{34}$ Several other states provide some mechanism for citizens to initiate charges with approval of a court or other government officer, ${ }^{35}$ but

charges if "the government's motion is contrary to manifest public interest because it is not based in the prosecutor's good faith discharge of her duties"); Gonzalez, 58 F.3d at 462 (reserving the question of whether the district court can ever deny an uncontested motion and noting that if it does, it can only do so in "exceptional circumstances"); United States v. Welborn, 849 F.2d 980, 983 n.2 (5th Cir. 1988) (holding district courts may deny untested motions only "in extremely limited circumstances in extraordinary cases . . . when the prosecutor's actions clearly indicate a betrayal of the public interest").

31 United States v. Cowan, 524 F.2d 504, 515 (5th Cir. 1975), cert. denied, Woodruff v. United States, 425 U.S. 971 (1976) (ruling that the federal court in Texas exceeded its authority by denying the Government's dismissal motion because the government had offered support for its decision, which was "not clearly contrary to the public interest").

32 Winne, 91 A.2d at 72-84.

${ }^{33}$ In Linda R.S. v. Richard D., the Supreme Court held that a mother did not have standing to compel a Texas prosecutor to bring charges against her husband for failure to pay support for her child who was born out of wedlock. Linda R.S. v. Richard D., 410 U.S. 614 (1973). The mother disagreed with the prosecutor who interpreted the statute to apply only to legitimate children. Id. at 614-16. In deciding the case, the Court noted that "a private citizen lacks a judicially cognizable interest in the prosecution or nonprosecution of another." Id. at 619; see also Juan Cardenas, The Crime Victim in the Prosecutorial Process, 9 HARV. J. L. \& PUB. POL'Y 357, 374 (1986) (explaining the history of private prosecution and noting that currently, "[c]ourts generally grant the public prosecutor the exclusive power to initiate criminal proceedings").

34 OHIO REv. CODE ANN. § 2935.09(D) (LexisNexis 2017) provides:

A private citizen having knowledge of the facts who seeks to cause an arrest or prosecution under this section may file an affidavit charging the offense committed with a reviewing official for the purpose of review to determine if a complaint should be filed by the prosecuting attorney or attorney charged by law with the prosecution of offenses in the court or before the magistrate.

This process was adopted in 2006 to replace an older process by which a private citizen could charge a crime directly without review by any government official. State v. Mbodji, 951 N.E.2d 1025, 1027 (Ohio 2011).

35 GA. CODE $§ 17-4-40$ (b)(1) (2010) (allowing citizen to make a request for criminal process to begin); IDAHO STAT. tit. $19 \S 501$ (2016) (allowing citizen to apply to court for an arrest warrant); MD. STAT. $\S 2-607(c)(6)$ (2015) (allowing citizen to apply to a commissioner who may issue a summons or, under limited circumstances, an arrest warrant); MINN. STAT. $\S \S 388.12,8.01$ (2016) (allowing citizens to appear before grand juries, petition district courts, appoint special prosecutors, and ask the governor to direct the attorney general to commence prosecution.); N.C. GEN. STAT. § 15A-304 (2005) (allowing private citizen to seek arrest 
most impose restrictions on private access to the criminal justice process. ${ }^{36}$ The majority of jurisdictions vest discretion entirely with the prosecutor and forbid private initiation of criminal charges. ${ }^{37}$

The fact that the law largely leaves the charging decision to the prosecutor does not end the inquiry. Professional standards govern prosecutors' decisions, but they offer limited guidance about when and whom to charge. Theories of punishment provide a starting point for analyzing this question. Prosecutors should start with a goal in order to determine who to punish and what sort of penalty to seek. Theories about the purpose of criminal penalties also help set the groundwork for understanding the limits of punishment in the criminal justice system. While there are many variations, the three most important theories of criminal justice for the purposes of this Article are retribution, deterrence, and other consequentialist theories.

\section{B. Justification}

Generally, retributive theories of justice rest on the assumption that guilty people deserve to be punished. ${ }^{38}$ The severity of the punishment ought to be proportional to

warrant or summons); S.C. CODE $§ 22-5-110$ (2011) (allowing private citizen to initiate a criminal case by requesting a magistrate to issue a summons); VA. STAT. $\$ 19.2-72$ (2016) (allowing private citizen complaints in writing). In Texas, private citizens can seek indictment directly from a grand jury. Douglas E. Baloof, Weighing Crime Victims' Interests in Judicially Crafted Criminal Procedure, 56 CATH. U. L. REV. 1135, 1142 (2007).

36 Taliaferro v. Locke, 182 Cal. App. 2d 752, 757 (1960) (rejecting mandamus to compel the district attorney to initiate prosecution); State ex rel. Freed v. Cir. Ct. of Martin County, 14 N.E.2d 910 (Ind. 1938) (nullifying lower court's order forcing the prosecutor to approve an affidavit in support of a criminal charge); Lutz v. Commonwealth, 505 A.2d 1356, 1356-57 (Pa. Commw. Ct. 1986) (denying petition for a writ of mandamus compelling the attorney General to investigate and prosecute a District Attorney for fraud).

37 Smith v. United States, No. 97-10025-PBS, 2013 WL 2154004, 2013 U.S. Dist. LEXIS 69778 , at $* 1$ (D. Mass. May 15,2013 ) (holding that a private citizen cannot file a criminal complaint in federal court and there is no right to require the government to initiate criminal proceedings); Roberts v. State, $280 \mathrm{Ga}$. App. 672, 674 (2006) (stating that "neither an accused nor a third-party private citizen may prosecute a criminal matter on his or her own"); Santiage v. Clerk Mag. of Clinton Dist. Ct., No. 0600397, 2006 WL 2848120, 2006 Mass. Super. LEXIS 431, at *2 (Mass. Super. Ct. Sept. 21, 2006) (denying a writ of mandamus ordering the clerk to accept an application for a criminal complaint); State ex rel. Wild v. Otis, 257 N.W.2d 361, 385 (Minn. 1977) (allowing private access to grand juries and district courts to use other mechanisms to petition for prosecution but denying the citizen the right to prosecute a crime himself); State v. Czartorsky, No. a-4384-07T4, 2009 WL 1228442, 2009 N.J. Super. Unpub. LEXIS 1087, at $* 4$ (N.J. Super. Ct. App. Div. 2009) (holding that a private citizen lacks standing to object to a lack of probable cause determination); Seeton v. Adams, 50 A.3d 268, 269-70 (Pa. Commw. Ct. 2012) (holding writ of mandamus cannot be used to correct the district attorney's allegedly mistaken view of a criminal statute); In re Richland County Mag.'s Ct, 389 S.C. 408, 414-15 (2010) (holding that a non-lawyer prosecuting a criminal misdemeanor charge engaged in the unauthorized practice of law and condemning the influence of private interests on public prosecution).

38 Michael Moore, Placing Blame: A General Theory of the Criminal law 104-88 (1997); JOHN KLEINIG, PUNISHMENT AND DESERT 67 (1973). 
the severity of the crime.$^{39}$ In turn, the gravity of the crime rests on the culpability of the wrongdoer and the harm to the victim. ${ }^{40}$ Philosophers have posed retribution as a theory for punishment for some time. Immanuel Kant reasoned that retribution was a moral imperative..$^{41}$ More recently, Herbert Morris argued that retribution is justified because criminals are essentially free riders. ${ }^{42}$ They benefit from the fact that everyone else in society has agreed not to commit crimes without adhering to that agreement themselves. ${ }^{43}$ Unlike tort law, theories of retribution are concerned not with compensating a victim, but with righting a wrong. ${ }^{44}$ In other words, retributive theories insist that punishment is a way of repairing a moral injury. ${ }^{45}$

Retributive theories of justice, at least in the absolute sense, support a right to accountability. In Morris' formulation, the victim and the rest of the public who have followed the rules have a moral right to see punishment for the person who abused the trust. ${ }^{46}$ If the criminal justice system exists to mete out punishment for crimes, then mandatory charging makes sense. It follows, without too many logical steps, that if a wrongdoer deserves to be punished, the state has an obligation to do so. ${ }^{47}$

The strong retributive theory of justice does not offer much guidance to policy makers who face external constraints. It offers little to prosecutors who have limited budgets or concerns about the effect that prosecutions might have on the stability of the government or the rule of law. ${ }^{48}$ Some scholars have modified retributivism by arguing that anyone guilty of a crime deserves punishment, but the moral duty gives way if it would result in some particularly bad result. ${ }^{49}$ If the negative consequence of prosecution passes that threshold, then policy makers and prosecutors would be justified in forgoing punishment. ${ }^{50}$ Others have conceded that retribution is not possible for every criminal act, ${ }^{51}$ but is, on the whole, a social good. Therefore, the

39 Hugo Adam Bedau, Classification-Based Sentencing: Some Conceptual and Ethical Problems, in [XXVII: CRIMINAl Justice] Nomos 89, 102 (J. Roland Pennock \& John W. Chapman eds., 1985).

40 Id.

41 Immanuel Kant, The Metaphysical Elements of Justice: Part I Of The METAPHYSICS OF MORALS 100-03 (John Ladd trans., 1965) (1797).

42 Herbert Morris, Persons and Punishment, 52 MoNIST 475, 477 (1968), reprinted in PUNISHMENT AND REHABILITATION 74, 75-76 (Jeffrie G. Murphy ed., 3d ed. 1985).

43 Id. at 477.

44 Jean Hampton, Correcting Harms vs. Righting Wrongs: The Goal of Retribution, 39 U.C.L.A L. REV. 1659, 1663 (1992).

45 Id. at 1665.

46 Morris, supra note 42 , at 477.

47 ANDREW VON HIRSCH, DOING JUSTICE 51 (1976); JoEl FEINBERG, DOING AND DESERVING: ESSAYS IN THE THEORY OF RESPONSIBILITY 103 (1970).

48 Michael Cahill, Retributive Justice in the Real World, 85 WASH. U. L. REV. 815, 820 (2007).
49 Id. at $830-31$.
50 MOORE, supra note 38, at 732-34.
51 Cahill, supra note 48 , at 828 . 
criminal justice system should maximize retribution while tending to other needs, such as budgetary restrictions.

Deterrence, a different rationale for criminal punishment, provides at least a theoretical basis for decisions and priorities driven by a limited budget and other concerns. Deterrence suggests that criminal actions are justified because they prevent future harms by imposing costs on illegal conduct. ${ }^{52}$ Unlike retributivism, deterrence focuses on the consequences of prosecution rather than moral imperatives. ${ }^{53}$ Thus, scholars argue that deterrence pushes policy makers and prosecutors to minimize social harm..$^{54}$ Criminal sanctions are valuable not because they impose punishment on the individual wrongdoer, but because they send a message to others. They impose a cost, which will presumably change the calculus of those contemplating similar anti-social acts in the future.

Deterrence provides greater guidance to policy makers because it involves a formula, albeit a difficult one to calculate. Society ought to expend resources and calibrate punishments so as to produce the greatest social value. Expending resources on the investigation and prosecution of some crimes rather than others will inevitably produce more value. ${ }^{55}$

In addition to retribution and deterrence, criminal sanctions can serve to reinforce and communicate core values. ${ }^{56}$ Like deterrence, the expressive function of the criminal law focuses on consequences of criminalization. Rather than calculating the social costs of wrongful acts, however, it measures the importance of social meaning and context. ${ }^{57}$ One of the important functions of the criminal justice system is communicating and reinforcing shared social values. ${ }^{58}$ Émile Durkeim argued that the penal system reinforces social solidarity by recognizing and broadcasting shared moral values. ${ }^{59} \mathrm{Law}$-abiding citizens experience the exercise of criminal sanctions as a validation and formulation of their social role - the bonds that tie them together. ${ }^{60}$ Those inclined to break the law may be immune to this social meaning but will nonetheless be deterred from future bad acts. ${ }^{61}$ Of course, given the diversity of

52 Dan M. Kahan, The Secret Ambition of Deterrence, 113 HARV. L. REV 413, 425 (1999) [hereinafter Kahan, Secret Ambition].

$53 \quad I d$. at 427.

54 Cahill, supra note 48 , at $817-18$.

55 Kahan, Secret Ambition, supra note 52, at 426-27.

56 Id. at 420-25. For a discussion of the theories of criminal punishment, see generally David GARland, Punishment AND MODERn SOCIETY (1996).

57 Kahan, Secret Ambition, supra note 52, at 419-20.

58 FeINBERG, supra note 47, at 100; Dan M. Kahan, What Do Alternative Sanctions Mean?, 63 U. CHI. L. REv. 591, 604 (1996) [hereinafter Kahan, Alternative Sanctions].

59 EMILE DURKheIM, THE DIVISION OF LABOR IN SOCIETY 102-03, 105 (1933). Many have criticized Durkheim for his overly rosy view of social solidarity or "common consciousness." Most prominently, Michel Foucault developed an alternate view of punishment in which is both projects moral values of some and disciplines or forces others into compliance. MICHEL Foucault, Discipline AND Punish 89-90, 194 (Alan Sheridan trans., 1979).

60 DURKHEIM, supra note 59, at 102.

61 Kahan, Alternative Sanctions, supra note 58, at 604. 
moral views, criminal law can also be a site of conflict and hegemonic proclamations about these norms. ${ }^{62}$

Scholars of transitional justice have emphasized this communicative value in arguing that retribution alone is a poor rationale for criminal prosecutions. ${ }^{63}$ In most fledgling democracies, prosecuting everyone involved in human rights violations during a previous repressive regime is impossible. Doing so might undermine the strength and durability of the new government. Therefore, these scholars suggest that it is appropriate and necessary to single out some individuals for prosecution. In a democratic system, this approach broadcasts the values central to the new regime while simultaneously strengthening faith in the rule of law without toppling the precarious new democracy.

\section{International Law}

This Article draws on international law because, unlike scholars of domestic criminal law, international law scholars have thought deeply about the duty to charge individuals for criminal wrongdoing. In addition, given the frequency of police shootings of African-American men in the United States, police use of force shares some similarities with the human rights abuses that invite the attention of international law scholars. By drawing the parallel, however, this Article does not intend to make an equivalence. The atrocity of human rights violations in the Americas and elsewhere are incomparable both in brutality and scale to police shootings. The comparison is nonetheless useful.

David Luban has defined crimes against humanity as crimes that undermine the social and political nature of humankind. ${ }^{64}$ People are naturally social creatures, but they need political organization in order to live together. ${ }^{65}$ Crimes against humanity are, in Luban's terms, politics turned "cancerous." 66 The complete failure to prosecute is a social pathology that threatens the system itself. ${ }^{67}$ While the scope and severity of police shootings of unarmed black men are not on the same scale as most international human rights violations, they also implicate our political organization. As they mount in number, they reflect a degeneration of the political world. ${ }^{68}$ Professor Luban also notes that crimes against humanity tend to target individuals within a group precisely for their membership in that group. ${ }^{69}$ Police shootings may be less consciously designed to terrorize a minority than many human rights

62 Kahan, Secret Ambition, supra note 52, at 421.

63 David Luban, Fairness to Rightness: Jurisdiction, Legality, and the Legitimacy of International Criminal Law, in PHILOSOPHY OF INTERNATIONAL LAW 569, 576-77 (Samantha Besson \& John Tasioulas eds., 2010).

64 David Luban, A Theory of Crimes Against Humanity, 29 YALE J. INT'L L. 85, 160 (2004) [hereinafter Luban, $A$ Theory].

65 Id. at 90.

66 Id.

67 Id.; Ruti Teitel, Transitional Justice and Judicial Activism-A Right to Accountability?, 48 CORNELl INT'L L. J. 385, 395 (2015) [hereinafter Teitel, Transitional Justice].

68 Luban, A Theory, supra note 64 , at 94.

69 Id. at 105 . 
violations, but that is the effect. ${ }^{70}$ While police shootings lack the scope and savagery typical of crimes against humanity, they share many of the other features. ${ }^{71}$ Part of the horror of human rights abuses is the impunity: the fact that the government tortured and abused citizens without accountability. ${ }^{72}$ Ironically, the very fact that police shootings have gone unpunished creates a similarity to these international atrocities.

The theoretical question of whether there ought to be a duty to charge for human rights violations has preoccupied international law scholars. While scholars tend to disagree about the scope of the duty to charge, most argue that some form of justice and revelation of the truth about past crimes is essential to promote reconciliation and reinforce democratic values. ${ }^{73}$ Diane Orentlicher, for instance, argues that there is an absolute duty to prosecute human rights violations of a prior regime. ${ }^{74}$ She reasons that a regime that fails to prosecute undermines the authority of the law and jeopardizes the transition to democracy. ${ }^{75}$ But drawing on retributive theories of justice, she also argues that atrocious crimes must be punished, especially those that single out racial, ethnic, or religious groups. ${ }^{76}$ Victims and others in society enjoy a right to accountability. ${ }^{77} \mathrm{Her}$ view of the critical role criminal justice plays in building a democracy echoes the philosophy of the trials at Nuremburg where the highly publicized cases provided a public condemnation of the evils of Nazi Germany. ${ }^{78}$

Most scholars, however, argue for a more pragmatic approach, combining prosecutions with other mechanisms to help establish and affirm social norms. Jaime Malamud-Goti asserts that democratic governments are required to proceed against perpetrators of mass atrocities even at the risk of military rebellion but the failure to punish all wrongdoers is not a breach of moral duty. ${ }^{79}$ Law is not merely a set of rules. ${ }^{80}$ It is a vehicle for social change. ${ }^{81}$ Deeply embedded, determined, and in turn

70 TA-Nehisi CoAtes, BetweEn the WORLd AND ME 81 (2015).

71 Luban, A Theory, supra note 64, at 98-99 (arguing that crimes against humanity are characterized by an ugliness, state-sponorship, which makes them categorically worse than ordinary crimes).

72 Id. at 117.

73 Maryam Kamali, Accountability for Human Rights Violations: A Comparison of Transitional Justice in East Germany and South Africa, 40 COLUM. J. TRANSNAT'L L. 89, 9192 (2001); Teitel, Transitional Justice, supra note 67, at 404-05.

74 Diane F. Orentlicher, Settling Accounts: The Duty to Prosecute Human Rights Violations of a Prior Regime, 100 YALE L. J. 2537, 2540 (1991).

$75 \quad I d$. at 2543.

$76 \quad$ Id. at 2594.

77 Id. at 2580, 2613-14.

78 Kristin Bohl, Breaking the Rules of Transitional Justice, 24 WISC. INT'L L. REV. 557, $558-59$ n.8 (2006).

79 Jaime Malamud-Goti, Transition Governments in the Breach: Why Punish State Criminals?, 12 HuM. RTS. Q. 1, 5 (1990).

80 Ronald M. Dworkin, The Model of Rules, 35 U. CH. L. REV. 1, 17 (1967). 
transformative, law itself plays an important role in the transition from totalitarian regimes to democratic governments. ${ }^{82}$

Some international law scholars argue that the rule of law requires prosecutions of prior regime abuses. For a set of complex reasons, full accountability is often impossible. ${ }^{83}$ Evidence is lost. ${ }^{84}$ The victims are dead or were so deeply incapacitated that they cannot recall details of their torture. ${ }^{85}$ Those most responsible insulated themselves from detection by issuing orders and never directly participating in the atrocities. ${ }^{86}$

Even when the evidence does exist, it is often hard to judge individuals for embracing what was, at the time, the prevalent norm. ${ }^{87}$ Individual perpetrators may have been following orders. They may have feared for their own lives if they did not. In Argentina, for example, the new democratic regime had to struggle with a law that provided a legal excuse for those who committed crimes because they were ordered to do so by superiors in the government or military. ${ }^{88}$ Police in America share the racism that is endemic to our country. As scholars have pointed out, the criminal charges incorporate that racism by asking jurors to determine whether or not the police officer was reasonably afraid for his or her own safety-a doctrine whose meaning depends on social stereotypes about black men. ${ }^{89}$

Even if the new regime finds a way (and many have) to bring criminal cases against individuals, trials are not always ideal for memorializing complex events. ${ }^{90}$ Rules of evidence, burdens of proof, and other procedural restrictions can undermine or mangle the truth in ways that break the narrative and make reconciliation more difficult. In guilty pleas and trials, unlike in truth commissions, defendants have incentives to deny the truth and undermine the credibility of the victim. ${ }^{91}$ If the defendant pleads guilty, then the victim and witnesses do not have the chance to recount their story.

International law scholarship offers insight into the problem of police shootings. The parallel shows how vital it is to enforce particular kinds of criminal laws. It highlights the structural cost to the democratic system of failing to do so. Police use

81 Mark A. Drumbl, Collective Violence and Individual Punishment: The Criminality of Mass Atrocity, 99 Nw. U. L. REV. 539, 588-89 (2005).

82 See Bohl, supra note 78, at 557.

83 See Malamud-Goti, supra note 79, at 2.

84 See Martha Minow, Vengeance and Forgiveness 45 (1998).

85 See Priscilla B. Hayner, Unspeakable Truths: Confronting State Terror and ATROCITY IN TIMES OF TRANSITION 1-2, 148-49 (2002).

86 Kamali, supra note 73 , at 132.

87 Id. at 99.

88 Malamud-Goti, supra note 79, at 2-3.

89 See generally Cynthia Kwei Yung Lee, Race and Self-Defense: Toward a Normative Conception of Reasonableness, 81 MiNN. L. REV. 367, 398-462 (1996) (analyzing how socially constructed stereotypes about blacks have shaped self-defense law).

90 MinOw, supra note 84 , at 47.

91 Drumbl, supra note 81, at 593-95. 
of unreasonable force against African-Americans qualifies as this type of crime because the failure to prosecute implicates fundamental democratic values. The failure to prosecute undermines the legitimacy and durability of our system as a whole. The scholarly debate about the role of criminal law enforcement in nascent democracies gives perspective on the potential role of the law, particularly of criminal trials, in the United States. Citizens crave retribution after periods of mass atrocity, but most scholars argue for a different justification for criminal law enforcement. Criminal justice may satisfy the desire and moral imperative of retribution, but most international law scholars agree that the law is more effective in communicating and inculcating a new set of values. Domestic criminal law has an important role to play in beginning to distance the country from its racist past, disentangling criminal law enforcement from its role in maintaining white supremacy.

\section{HOW TO HANDLE THE CASE?}

Failing to prosecute police for using unreasonable force against AfricanAmericans has a corrosive effect on democracy. It deepens a distrust that has been breeding for generations. ${ }^{92}$ As many scholars and activists have argued, the American criminal justice system was born and nurtured on racism. ${ }^{93}$ It has remained a tool of racial domination while retaining the legitimating semblance of a colorblind system. ${ }^{94}$ Like regimes in transition from repressive totalitarianism to democracy, our own system needs to shed the past. While, of course, this cannot be done in an instant, one step toward embracing a new set of values must involve prosecution of police brutality. High-profile cases can serve to both embrace and broadcast new values. The dysfunction in our system can, ironically, provide an opportunity to disavow the past and begin to introduce new values for the future.

Taking this progr2ess as the goal, it seems clear that there ought to be a limited duty to charge in police shooting cases. Prosecuting police for excessive use of force is difficult. ${ }^{95}$ Cases are often hard to prove. ${ }^{96}$ Prosecutors are often reluctant to charge police because the prosecutors work closely with the department and rely on officers to bring cases. ${ }^{97}$ Even when it seems as if the proof is readily available and prosecutors do pursue the case, juries often fail to convict. ${ }^{98}$ As with human rights abuses under totalitarian regimes, it is complicated to impose a new set of norms on

92 See generally COATES, supra note 70.

93 Randall KenNEDY, RACE, CRIME, AND THE LAW 29-135 (1998); Angela J. Davis, Benign Neglect of Racism in the Criminal Justice System, 94 MiCH. L. REv. 1660, 1662-64 (1996).

94 Nicole Gonzalez Van Cleve \& Lauren Mayes, Criminal Justice Though "Colorblind" Lenses: A Call to Examine the Mutual Constitution of Race and Criminal Justice, 40 L. \& SOC. INQUIRY 406, 407-08 (2015).

95 Kate Levine, Who Shouldn't Prosecute the Police, 101 IOWA. L. REv. 1447, 1464-65 (2016).

96 Id. at 1468 .

97 Id. at $1466-68$.

98 Rachel A. Harmon, When is Police Violence Justified?, 102 Nw. U. L. REv. 1119, 1145 (2008). 
actors who were operating in an unjust system. The law governing use of force is unclear. ${ }^{99}$ Racist perceptions can fuel excuses for justification, which juries may endorse. ${ }^{100}$ To charge and prosecute every alleged case would not only be unjust, but could potentially compound the problem. The acquittals and dropped charges in the Freddie Gray case, for instance, did not transmit a message about racial equality and the criminal justice system. ${ }^{101}$ In fact, it transmitted quite the opposite message.

It would be an abuse of discretion to fail to prosecute a police officer for shooting an unarmed black man if there is sufficient evidence to support the charge. Prosecutors have a duty to do justice. ${ }^{102}$ Given the history of race and the criminal justice system - as well as the impact the failure to prosecute has had on AfricanAmerican communities in particular and the criminal justice system in generalfailure to charge in these sorts of cases amounts to an abdication of that duty. ${ }^{103}$ Of course, even this new obligation leaves prosecutors in charge of determining whether sufficient evidence exists, but it imposes an additional burden on them in this class of cases. The duty implies an obligation to investigate. ${ }^{104}$ It would be insufficient to conclude that a police shooting does not warrant charges unless the prosecutor has thoroughly investigated the case and determined that there is insufficient evidence to support criminal charges. ${ }^{105}$ In other words, a prosecutor must investigate even when doing so would alienate the police department on which the prosecutor depends. ${ }^{106}$

Criminal prosecutions ought to serve a salutary function. Just as in the international context, these trials should expose racial injustice and bias in criminal law enforcement. The first step to purging racism is to admit in a public way that it exists. Ideally, a public trial can educate the populace and reinforce or even help forge new national values. ${ }^{107}$ While victims and activists seek retribution, the desire

99 Id. at 1125-27.

100 See KENNEDY, supra note 93, at 256-78.

101 Sung \& Shoichet, supra note 2.

102 Model Rules of Prof'L Conduct r. 3.8(a) (AM. BAR ASS'N 1983); see also Standards for Criminal Justice Prosecution Function and Defense Function r. 31.2(c) (AM. BAR ASS'N 1993) ("The duty of the prosecutor is to seek justice, not merely to convict.").

103 See KENNEDY, supra note 93.

104 Alexa P. Freeman, Unscheduled Departures: The Circumvention of Just Sentencing for Police Brutality, 47 HASTINGS L.J. 677, 719 (1996).

105 While prosecutors rely on police and other agencies to investigate criminal wrongdoing, they have an affirmative obligation to investigate when other agencies fail to do so. Standards for Criminal Justice Prosecution Function and Defense Function r. 33.1(a) (AM. BAR Ass'N 1993). They are barred from discriminating on the basis of race or using any other improper considerations in exercising their discretion about whether or not to investigate. Id. at r. 3-3.1(b).

106 See Levine, supra note 95, at 1444-45 (arguing that local district attorneys should not prosecute police). But see Bruce A. Green \& Rebecca Roiphe, Prosecutors' Conflicts of Interest, 58 B.C. L. REV. 2, 6 (forthcoming 2017) (arguing that recusal or disqualification may not solve the problem because alternate prosecutors like Attorneys General and independent prosecutors may also suffer from conflicts of interest in this area).

107 Kahan, Secret Ambition, supra note 52, at 421-22; see also William J. Brennan, Jr., The Criminal Prosecution: Sporting Event or Quest for Truth? A Progress Report, 68 WASH. U. L. 
for punishment is only a partial purpose of the criminal justice system. In addition, as international scholars have demonstrated, part of the purpose of the law in transitional moments is to reinforce a new set of values. Public prosecutions of police who can be proved guilty of using excessive force against African-Americans will offer a counter-narrative. If the criminal justice system in America tends to tell the story of dangerous black men plaguing society with brutal crimes, the prosecution of the police can offer a new narrative, just as the innocence movement has. ${ }^{108}$

Even if prosecutors were to charge every police shooting that the evidence supports, there are limits to the criminal law's capacity to serve an expressive function. Trials can be a valuable tool for articulating shared values, but they are often inadequate. State and federal governments should look to supplement these trials with a domestic version of "truth commissions." 109 As international law scholars have argued, these arenas offer a cathartic experience for victims while involving the entire community in a reevaluation of beliefs and core values. ${ }^{110} \mathrm{~A}$ limited duty to prosecute should accommodate alternate mechanisms like truth commissions, which have proved effective in instilling new values. ${ }^{11}$ They have the benefit of allowing a full narrative, which exceeds the scope of a criminal trial. Legislative hearings might serve this function on a smaller scale. In this setting, victims and activists could speak without the constraints of evidentiary rules. Moreover, police could participate without the fear of criminal punishment."This type of dialog is a necessary complement to prosecution in moving away from the racial injustice that has marred the criminal justice system and jeopardized the foundations of democracy. If the limited duty to prosecute in police use-of-force cases is seen as animated by a desire to deter criminal acts and create a new narrative, then it is consistent with other mechanisms, like truth commissions. ${ }^{112}$

\section{CONCLUSION}

The duty to charge in police shooting cases derives from the expressive and deterrent value of criminal law. It is not, therefore, absolute. Unlike retributivism, these criminal justice theories cannot support a duty to charge every case. They do, however, point to the severe need to address this type of crime. They call on the criminal justice system to view this crime, which implicates the foundation of democracy, differently. Thus, there is an absolute duty to investigate police killings of unarmed black men, and there is a limited duty to charge when the evidence supports conviction.

Q. 1, 17 (1990) ("[C]riminal trials are and are intended to be richly symbolic and educational - that is part of their function in a society governed by the rule of law.").

108 Bruce A. Green \& Ellen Yaroshefsky, Prosecutorial Accountability 2.0, 92 NOTRE DAME L. REv. 51, 52-53 (forthcoming 2017).

109 See HAYNER, supra note 85 at 29; Ruth G. Teitel, Transitional Justice Genealogy, 16 Harv. Human RTS. J. 69, 79-80 (2003) [hereinafter Teitel, Genealogy].

110 Teitel, Genealogy, supra note 109, at 80.

111 Teitel, Transitional Justice, supra note 67, at 404.

112 Id. 
- 